\section{REFERENCES}

Allen, R. J. L. (1940). Biochem. J. 34, 858.

Aten, A. H. W. jun. \& Hevesy, G. (1938). Nature, Lond., $142,111$.

Berenblum, I. \& Chain, E. (1938). Biochem. J. 32, 295.

Blackwood, J. H. (1934). Biochem. J. 28, 1346.

Garton, G. A. \& Popják, G. (1952). Biochem. J. 50, xvi.

Graham, W. R. jun., Jones, T. S. G. \& Kay, H. D. (1936). Proc. Roy. Soc. B, 120, 330.

Hilditch, T. P. \& Maddison, L. (1941). Biochem. J. 35, 24.

Kaplan, N. O. \& Greenberg, D. M. (1944). J. biol. Chem. 156, 511.

Lintzel, W. (1934). Z. Zücht. B, 29, 219.
Maynard, L. A., McCay, C. M., Ellis, G. H., Hodson, A. Z. \& Davis, G. K. (1938). Mem. Cornell agric. Exp. Sta. no. 211.

Meigs, E. B., Blatherwick, N. R. \& Cary, C. A. (1919). J. biol. Chem. 37, 1.

Popják, G. (1946). Biochem. J. 40, 608.

Popják, G. (1951-2). Nutr. Abstr. Rev. 21, 535.

Popják, G. \& Beeckmans, M.-L. (1950). Biochem. J. 46, 99.

Popják, G., Hunter, G. D. \& French, T. H. (1953). Biochem. J. 54, 238.

Popják, G. \& Muir, H. (1950). Biochem. J. 46, 103.

Shaw, J. C. \& Petersen, W. E. (1940). J. Dairy Sci. 23, 1045.

Taurog, A., Entenman, C. \& Chaikoff, I. L. (1944). J. biol. Chem. 156, 385.

Veall, N. (1948). Brit. J. Radiol. N.S., 21, 347.

Voris, L., Ellis, G. \& Maynard, L. A. (1940). J. biol. Chem. 133, 491.

\title{
The Biochemistry of Organo-tin Compounds
}

\section{DIETHYLTIN DICHLORIDE AND TRIETHYLTIN SULPHATE}

\author{
BY W. N. ALDRIDGE AND JILL E. CREMER \\ Medical Research Council Unit for Research in Toxicology, Serum Research Institute, Carshalton
}

\section{(Received 9 May 1955)}

The potential value of organo-tin compounds as fungicides (Van der Kerk \& Luijten, 1954) has stimulated an examination of their toxicity. The older work of White (1881) has been confirmed and extended by Stoner, Barnes \& Duff (1955). Both diethyltin dichloride and triethyltin sulphate are highly toxic substances, and in discussing their mode of action the authors suggest the probable importance of a biochemical lesion. Interest in these compounds is increased by the report of many deaths in France after the oral administration of diethyltin dichloride as a treatment for boils (Brit. med. J. 1954).

The work described in this paper represents an attempt to define their biochemical action. Stoner et al. (1955) show that triethyltin sulphate and diethyltin dichloride do not produce the same clinical symptoms in rats. Furthermore, rats are protected from a lethal dose of diethyltin dichloride by 2:3-dimercaptopropanol (BAL); this is not possible with triethyltin sulphate. Triethyltin compounds are at least 100 times more effective as fungicides than are diethyltin compounds (Van der Kerk \& Luijten, 1954). Differences are also apparent in their action on the biochemical behaviour of rat-brain brei and rat-liver mitochondria.

Triethyltin sulphate and diethyltin dichloride ionize in aqueous solution to give the univalent triethyltin and the bivalent diethyltin ions
(Luijten \& Van der Kerk, 1952; Smyth, 1941). Irrespective of the extent of their ionization, we have compared the bivalent diethylstannyl and phenylarsino groups and the univalent triethylstannyl and diphenylarsino groups. Like phenylarsenious acid, diethyltin dichloride inhibits $\alpha$-keto acid oxidases, a result which is in agreement with the 'dithiol theory' of Peters (1948). Triethyltin sulphate, on the other hand, has little affinity for SH groups and is a powerful inhibitor of the phosphorylation processes which are linked to oxidation.

\section{EXPERIMENTAL}

Rat-brain brei. Rats were killed by a blow on the back of the neck and the brain was quickly removed and rinsed in ice-cold $0.9 \%(w / v) ~ N a C l$. The tissue (l brain is approximately $1.2 \mathrm{~g}$.) was squeezed through the nozzle of a $5 \mathrm{ml}$. all-glass syringe into $6 \mathrm{ml}$. ice-cold $0 \cdot 1 \mathrm{~m}$ sodium phosphate buffer $\mathrm{pH} 7 \cdot 4$. The suspension was gently sucked in and out of the syringe until a smooth dispersion was produced (6-8 times up and down is usually required). A portion (1 ml.) of this suspension was added to the substrate in phosphate buffer (total volume in flasks, $3 \mathrm{ml}$.). The centre well of each flask contained $0.15 \mathrm{ml} .20 \%(\mathrm{w} / \mathrm{v})$ $\mathrm{KOH}$ for $\mathrm{CO}_{2}$ absorption and the gas phase was air. After warming to $37^{\circ}$, readings of $\mathrm{O}_{2}$ uptake were taken at intervals up to $70 \mathrm{~min}$. Such preparations will continue to oxidize lactate, glucose and pyruvate for up to $3 \mathrm{hr}$.

Rat-liver mitochondria. A fow of the initial experiments were carried out with rat-liver mitochondria isolated by the procedure of Schneider (1948). A modified procedure using 
lower centrifugal forces and a final washing with $0.9 \%$ $(\mathrm{w} / \mathrm{v}) \mathrm{KCl}$ was used for most of the experiments. Rats were killed by a blow on the head, the liver was quickly removed and excess of blood rinsed off with distilled water. The liver, after weighing, was disrupted in $75 \mathrm{ml}$. ice-cold $0.25 \mathrm{M}$ sucrose, using a Nelco homogenizer (Measuring and Scientific Instruments, London) at $5000 \mathrm{rev} . / \mathrm{min}$. for $1.5 \mathrm{~min}$. The 'nuclear fraction' was centrifuged at $600 \mathrm{~g}$ at $0^{\circ}$ for $10 \mathrm{~min}$. The supernatant was poured off through four layers of surgical gauze and the mitochondria were sedimented at $5000 \mathrm{~g}$ at $0^{\circ}$ for $15 \mathrm{~min}$. (Strittmatter \& Ball, 1954). The supernatant was discarded and the particles were suspended in ice-cold $0.9 \%(\mathrm{w} / \mathrm{v}) \mathrm{KCl}$ solution and sedimented at $2500 \mathrm{~g}$ at $0^{\circ}$ for $5 \mathrm{~min}$. After removal of the supernatant, the mitochondria were suspended in ice-cold $0.9 \%(\mathrm{w} / \mathrm{v}) \mathrm{KCl}$ to a volume in $\mathrm{ml}$. equal to twice the weight of the liver in $\mathrm{g}$. Such preparations were stored in an ice bath until used, usually within $1 \mathrm{hr}$. of preparation. Protein determinations by the biuret method of Robinson \& Hogden (1940) indicated a consistent recovery of mitochondria. Such preparations are consistently active, oxidizing all the tricarboxylic acid cycle substrates, octanoate and $\beta$-hydroxybutyrate, and esterifying inorganic phosphorus. The general technique, essentially that of Judah (1951), was as follows: Each flask contained $3 \mathrm{ml}$. of a solution containing $0.00123 \mathrm{M}$ adenosine $5^{\prime}$-phosphate (AMP), $0.0067 \mathrm{M}-\mathrm{MgSO}_{4}, 0.045 \mathrm{M}-\mathrm{KCl}, 7.25 \times 10^{-6} \mathrm{M}$ cyto-

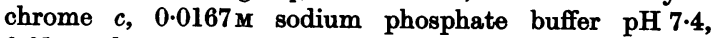
$0.01 \mathrm{~m}$ substrates as neutralized sodium or potassium salts and mitochondria equivalent to $167-333 \mathrm{mg}$. wet wt. of original liver. The centre well of each flask contained $0.15 \mathrm{ml} .20 \%$ (w/v) $\mathrm{KOH}$ for $\mathrm{CO}_{2}$ absorption and the gas phase was air. The mitochondria in ice-cold $0.9 \%(w / v)$ $\mathrm{KCl}$ were added to the above components at room temp., the flasks warmed to $37^{\circ}$ and readings taken from 10 to $70 \mathrm{~min}$. Variations in this general procedure are given in the legends of the particular experiments.

Special chemicals. Succinic acid, sodium citrate, lithium lactate, glucose, $\boldsymbol{p}$-phenylenediamine (British Drug Houses, Poole), adenosine $5^{\prime}$-phosphoric acid (AMP), sodium pyruvate and glutathione (GSH) (Roche Products Ltd., Welwyn), $\alpha$-oxoglutaric acid, L-malic acid, oxaloacetic acid, sodium DL- $\beta$-hydroxybutyrate (Light and Co., Colnbrook), L-glutamic acid (Ashe Laboratories, London) and 2:3dimercaptopropanol (BAL) (Boots Pure Drug Co., Nottingham) were used.

Cytochrome $c$ was prepared from $27 \mathrm{lb}$. cow heart by the method of Keilin \& Hartree (1952). The product (1.58 g.) was $73 \%$ pure, using $\epsilon \mathbf{2 . 8 1} \times 10^{4}$ for reduced cytochrome $c$ at $550 \mathrm{~m} \mu$. and a mol. wt. of 16500 (Umbreit, Burris \& Stauffer, 1951).

Coenzyme I (Co I) was prepared from baker's yeast by the method of Kornberg \& Pricer (1953). By processing $112 \mathrm{lb}$. yeast (British Fermentation Products, London) and proceeding to the acetone powder stage after removal of silver, a yield of $5.9 \mathrm{~g}$. was obtained. Assay of this material by the method of Gutcho \& Stewart (1948), but using $\epsilon 6.22 \times 10^{3}$ for reduced Co I at $340 \mathrm{~m} \mu$. (Horecker \& Kornberg, 1948) indicated a purity of $74 \%$. A solution of reduced Co I suitable for the determination of Co Icytochrome $c$ reductase was prepared by adding $3 \mathrm{ml}$. $0.4 \%(w / v) \mathrm{Na}_{2} \mathrm{~S}_{2} \mathrm{O}_{4}$ in $1 \%(w / v) \mathrm{NaHCO}_{3}$ to $23.2 \mathrm{mg}$. Co I. This solution was heated in a boiling-water bath for exactly $1 \mathrm{~min}$., cooled in ice and diluted to $25 \mathrm{ml}$. with a cold solution containing $1 \%(w / v) \mathrm{Na}_{2} \mathrm{CO}_{3}$ and $1 \%(w / v)$
$\mathrm{NaHCO}_{3}$. This solution was aerated rapidly until a constant optical density at $340 \mathrm{~m} \mu$. was obtained. The solution was stored at $+2^{\circ}$ and before use was brought to $\mathrm{pH} 7 \cdot 6$ with $0.5 \mathrm{M}-\mathrm{KH}_{2} \mathrm{PO}_{4}$.

The barium salt of adenosine triphosphoric acid (ATP) was prepared from rabbit muscle by the method of LePage (1949). The $\mathrm{Ba}$ salt was converted into the $\mathrm{K}$ salt by treatment with Amberlite 1 R-120 (K-cycle).

Hexokinase was prepared from baker's yeast by the method of Berger, Slein, Colowick \& Cori (1946), and the preparation carried to their stage $3 a$. When assayed by their procedure (but at $37^{\circ}$ instead of $30^{\circ}$ ) our preparation had an activity of $5350 \mathrm{units} / \mathrm{ml}$. When oxidative phosphorylation was being measured 100 units/flask were added.

Inhibitors. Diethyltin dichloride was used as a stock solution, $2.0 \mathrm{mg} . / \mathrm{ml}$. $\left(8 \times 10^{-8} \mathrm{M}\right)$. Triethyltin hydroxide, $26.2 \mathrm{~g}$. $(0 \cdot 118 \mathrm{~mole})$, was dissolved in $130 \mathrm{ml}$. acetone, filtered and $12.0 \mathrm{ml}$. $(0.060 \mathrm{~mole}) 5 \mathrm{M}-\mathrm{H}_{2} \mathrm{SO}_{4}$ were added with vigorous stirring. A further $130 \mathrm{ml}$. acetone were added, the mixture was cooled and the solid filtered off. After washing with acetone, it was resuspended in acetone, filtered off and dried in air and finally in vacuo. Yield, 23.5 g. triethyltin sulphate (stock solution $10 \mathrm{mg} . / \mathrm{ml} ., 3.94 \times 10^{-2} \mathrm{M}$ ). A stock solution of phenylarsenious acid ( $\mathrm{Na}$ salt) was prepared by adding $5 \mathrm{ml} .0 \cdot 1 \mathrm{~N}-\mathrm{NaOH}$ to $30 \mathrm{mg}$. phenylarsine oxide and gently warming in a water bath at $60-70^{\circ}$. After addition of $5 \mathrm{ml}$. water the solution was stored at $+2^{\circ}$. A fresh solution was prepared every week. A stock solution of diphenylchloroarsine $(2.64 \mathrm{mg} . / \mathrm{ml}$.) was prepared in $60 \%$ $(v / v)$ ethanol. Before use it was diluted 50 times with water to give a concentration of $2 \times 10^{-4} \mathrm{M}$ in $1.2 \%(v / v)$ ethanol. Further dilutions were made in $1.2 \%(v / v)$ ethanol and a maximum of $1 \mathrm{ml}$. of this solution in a total of $3 \mathrm{ml}$. was used for any experiment. $p$-Chloromercuribenzoic acid was prepared by the method of Whitmore \& Woodward (1947) and a stock solution $\left(1 \times 10^{-3} \mathrm{M}\right)$ was prepared by dissolving in dilute $\mathrm{NaOH}$ and quickly neutralizing to $\mathrm{pH} \mathbf{7 \cdot 4}$ with $\mathrm{HCl}$.

Anaerobic glycolysis. Lactic acid was estimated by the technique of Barker \& Summerson (1941). The same results were obtained when additional copper-lime treatments to remove interfering substances were used (Hullin \& Noble, 1953). Anaerobic glycolysis was studied by using a ground rat-brain preparation, the procedure being essentially that of Krimsky \& Racker (1949), see Table 4.

Reactivity of inhibitors with SH groups. The use of the nitroprusside method of Grunert \& Phillips (1951) for the determination of SH groups remaining after treatment with inhibitor was unsatisfactory. The method of Stocken \& Thompson (1946b) was modified by using 2:6-dichlorophenolindophenol in place of porphyrindin. It is well known that SH compounds interfere in the determination of L-ascorbic acid using 2:6-dichlorophenolindophenol (O'Brien, 1944), and we have found that this dye is readily reduced by GSH, cysteine, thiomalic acid, kerateine and BAL at $\mathrm{pH} 7.4$ in phosphate buffer. The rate of reduction of the dye by an SH compound with and without the inhibitor is followed by reading the optical density at $620 \mathrm{~m} \mu$., using a Unicam D.G. spectrophotometer, see Table 1.

$\alpha-K$ eto acid determinations. Pyruvate was determined in rat-brain brei by the method of Friedmann \& Haugen (1943), using toluene to extract the 2:4-dinitrophenylhydrazones. For the determination of the total $\alpha$-keto acid produced by rat-liver mitochondria, the hydrazones were extracted by shaking with $3 \mathrm{ml}$. diethyl ether instead of 
toluene. In a few experiments (cf. Table 9) the sensitivity of the method was increased fourfold by using $5 \mathrm{ml}$. trichloroacetic acid (TCA) filtrate instead of $3 \mathrm{ml}$. and extracting the hydrazones from the ether extract (3 ml.) with $2.5 \mathrm{ml} .10 \%(\mathrm{w} / \mathrm{v}) \mathrm{Na}_{2} \mathrm{CO}_{3}$ solution instead of $6 \mathrm{ml}$. A portion $(2 \mathrm{ml}$.) of this extract was treated with $2 \mathrm{ml}$. $1.5 \mathrm{~N}-\mathrm{NaOH}$ solution and the colour read after $10 \mathrm{~min}$. at $520 \mathrm{~m} \mu$. in $1 \mathrm{~cm}$. cells, using a Unicam S.P. 600 spectrophotometer. The quotient of the optical density at $420 \mathrm{~m} \mu$. over that at $520 \mathrm{~m} \mu$. was routinely determined and has been found to be $1 \cdot 30 \pm 0.004$ for pyruvate and $2 \cdot 04 \pm 0.011$ for $\alpha$-oxoglutarate. In representative experiments we have checked the identity of the $\alpha$-keto acid measured, using the chromatographic method of El Hawary \& Thompson (1953). Samples from Warburg flasks were deproteinized (final concentration $9 \% \mathrm{w} / \mathrm{v}$ TCA) and were stored in an ice bath before the determination of $\alpha$-keto acids. No precautions other than cooling have been made to prevent the breakdown of oxaloacetate to pyruvate, and chromato. graphic examination has shown that both are present. The total $\alpha$-keto acids produced 3, 6, 9 and 12 min. after the addition of inhibitor by rat-liver mitochondria metabolizing citrate, L-malate and L-glutamate were determined. With citrate as substrate and phenylarsenious acid as inhibitor the $\alpha$-keto acid level increased until the $\mathrm{O}_{2}$ uptake had decreased by $50 \%$. Further decreases in $\mathrm{O}_{2}$ uptake are accompanied by a fall in $\alpha$-keto acid level. Therefore, for the experiments described in Tables 6 and 7, amounts of inhibitor to produce not more than $30 \%$ inhibition of $\mathrm{O}_{2}$ uptake were used.

Co I-cytochrome c reductase. The method of Hogeboom (1949) was used with mitochondria prepared by the method of Schneider (1948). The solution for each determination contained potassium phosphate $\mathrm{pH} 7.6 \quad 0.025 \mathrm{M}$, nicotinamide $0.0205 \mathrm{M}, \mathrm{KCN} 7.5 \times 10^{-5} \mathrm{M}$, cytochrome $c$ $1.9 \times 10^{-5} \mathrm{M}$, reduced Co I 4.5 $\times 10^{-5} \mathrm{M}, 0.2 \mathrm{ml}$. mitochondria suspension in $0.25 \mathrm{~m}$ sucrose equivalent to $0.66 \mathrm{mg}$. wet wt. of original liver tissue, and water to $4 \mathrm{ml}$. The control contained no mitochondrial suspension. Triethyltin sulphate was added from a stock solution (10 mg./ml.)

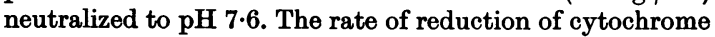
$c$ was followed by the rise in optical density at $549 \mathrm{~m} \mu$., using $1 \mathrm{~cm}$. cells in a Unicam S.P. 650 quartz spectrophotometer. The rate of reduction was calculated from the early straight line portion of the curve. No reduction of cytochrome $c$ occurred without the addition of reduced Co I or mitochondrial suspension. All determinations were at room temp. $\left(18-20^{\circ}\right)$.

Dehydrogenases. A technique was used in which high concentrations of keto acid blocking agents have been

\section{Table 1. Reaction of organo-tin, organo-arsenic and organo-mercury compounds with SH groups of glutathione and 2:3-dimercaptopropanol}

The solution of SH compound $(1.0 \mathrm{ml}$.) was added to a mixture of $1.0 \mathrm{ml}$. solution of the compounds to be tested and $7 \mathrm{ml}$. 0.067 $\mathrm{M}$ phosphate buffer $\mathrm{pH} \mathrm{7.4}$. After $5 \mathrm{~min}$. 1.0 ml. 2:6-dichlorophenolindophenol (70-90 $\mu \mathrm{g}$.) was added and the rate of decolorization determined from the decrease in optical density at $620 \mathrm{~m} \mu$., using a Unicam D.G. spectrophotometer. Room temperature $18-20^{\circ}$. Under these conditions there is a linear relation between dye concentration and optical density. The time for $40 \%$ decolorization was determined graphically. $R$ is the quotient of the molar concentration of organo-metal ion over the molar concentration of SH compound.

\begin{tabular}{|c|c|c|c|c|}
\hline $\begin{array}{l}\text { Concn. of SH } \\
\text { compound } \\
\text { (M) }\end{array}$ & $\begin{array}{l}\text { Concn. of } \\
\text { organo-metal } \\
\text { compound } \\
\text { (M) }\end{array}$ & $R$ & $\begin{array}{l}\text { No organo- } \\
\text { metal } \\
\text { compound } \\
\text { (sec.) }\end{array}$ & $\begin{array}{l}\text { With organo- } \\
\text { metal } \\
\text { compound } \\
\text { (sec.) }\end{array}$ \\
\hline \multicolumn{4}{|c|}{$p$-Chloromercuribenzoic acid } & $\cdot$ \\
\hline $\begin{array}{l}\text { GSH, } 6 \times 10^{-5} \\
\text { BAL, } 2 \cdot 3 \times 10^{-5}\end{array}$ & $\begin{array}{l}8.1 \times 10^{-5} \\
8 \cdot 1 \times 10^{-5}\end{array}$ & $\begin{array}{l}1 \cdot 3 \\
3 \cdot 2\end{array}$ & $\begin{array}{r}118 \\
38\end{array}$ & $\begin{array}{l}\infty \\
\infty\end{array}$ \\
\hline \multicolumn{5}{|c|}{ Phenylarsenious acid } \\
\hline $\begin{array}{l}\text { GSH, } 5 \cdot 1 \times 10^{-5} \\
\text { BAL, } 2 \cdot 2 \times 10^{-5}\end{array}$ & $\begin{array}{l}8.9 \times 10^{-4} \\
4.4 \times 10^{-5}\end{array}$ & $\begin{array}{r}17 \cdot 4 \\
2 \cdot 0\end{array}$ & $\begin{array}{r}125 \\
46\end{array}$ & $\begin{array}{c}750 \\
10 \% \text { in } 15 \mathrm{~min} .\end{array}$ \\
\hline \multicolumn{5}{|c|}{ Diphenylchloroarsine } \\
\hline $\begin{array}{l}\text { GSH, } 5 \cdot 1 \times 10^{-5} \\
\text { BAL, } 2 \cdot 2 \times 10^{-5}\end{array}$ & $\begin{array}{l}2 \cdot 0 \times 10^{-4} \\
1.0 \times 10^{-4}\end{array}$ & $\begin{array}{l}3 \cdot 9 \\
4 \cdot 6\end{array}$ & $\begin{array}{r}125 \\
46\end{array}$ & $10 \%$ in 30 min. \\
\hline \multicolumn{5}{|c|}{ Arsenious acid } \\
\hline $\begin{array}{l}\text { GSH, } 5 \times 10^{-5} \\
\text { BAL, } 2 \cdot 3 \times 10^{-5}\end{array}$ & $\begin{array}{l}1.8 \times 10^{-3} \\
1.8 \times 10^{-3}\end{array}$ & $\begin{array}{l}36 \\
78\end{array}$ & $\begin{array}{r}118 \\
38\end{array}$ & $\begin{array}{c}118 \\
\infty\end{array}$ \\
\hline \multicolumn{5}{|c|}{ Triethyltin sulphate } \\
\hline $\begin{array}{l}\text { GSH, } 5 \times 10^{-5} \\
\text { BAL, } 2 \cdot 3 \times 10^{-5}\end{array}$ & $\begin{array}{l}7 \cdot 8 \times 10^{-4} \\
7 \cdot 8 \times 10^{-4}\end{array}$ & $\begin{array}{l}15 \cdot 6 \\
33 \cdot 9\end{array}$ & $\begin{array}{r}118 \\
38\end{array}$ & $\begin{array}{r}135 \\
55\end{array}$ \\
\hline \multicolumn{5}{|c|}{ Diethyltin dichloride } \\
\hline $\begin{array}{l}\text { GSH, } 5 \times 10^{-5} \\
\text { BAL, } 2 \cdot 3 \times 10^{-5} \\
\text { BAL, } 2 \cdot 2 \times 10^{-5}\end{array}$ & $\begin{array}{l}9.7 \times 10^{-4} \\
9.7 \times 10^{-4} \\
4.5 \times 10^{-5}\end{array}$ & $\begin{array}{r}19 \cdot 4 \\
42 \cdot 2 \\
2 \cdot 0\end{array}$ & $\begin{array}{r}112 \\
38 \\
46\end{array}$ & $\begin{array}{c}172 \\
6 \% \text { in } 15 \mathrm{~min} .\end{array}$ \\
\hline
\end{tabular}

* The solution became slightly turbid, but visually there was no appreciable decolorization of the dye. 
avoided. The conditions necessary, i.e. Co I concentration, $\mathrm{pH}$ and substrate concentration, to give a reasonable amount of Co I reduction have been calculated from the equilibrium constants of lactic dehydrogenase (Racker, 1950), L-malic dehydrogenase (Burton \& Wilson, 1953) and L-glutamic dehydrogenase (Olson \& Anfinsen, 1953). The rate of reduction of Co I was followed by the rise in optical density at $340 \mathrm{~m} \mu$. in $1 \mathrm{~cm}$. quartz cells, using a Unicam S.P. 650 spectrophotometer. The details of the experiments with an extract of acetone-dried rat liver and rat-liver mitochondria are given in Table 10. In order to use a low Co I concentration lactic dehydrogenase was studied by catalysing the reduction of pyruvic acid to lactic acid by reduced Co $I$. The equilibrium point of this reaction at pH 7.4 favours the reaction proceeding in this direction (Racker, 1950). The solution for each determination contained potassium phosphate $\mathrm{pH} 7 \cdot 60.025 \mathrm{M}$, nicotinamide $0.0205 \mathrm{M}, \mathrm{KCN} 7.5 \times 10^{-5} \mathrm{M}$, sodium pyruvate $0.01 \mathrm{M}$, reduced Co I $1.04 \times 10^{-4} \mathrm{M}, 0.4 \mathrm{ml}$. of a rat-liver extract (cf. Table 10) equivalent to $0.8 \mathrm{mg}$. original acetone-dried rat liver, and water to $4 \mathrm{ml}$. The control contained no Co I. Triethyltin sulphate was added from a stock solution (10 mg./ml.) neutralized to $\mathrm{pH} \mathrm{7 \cdot 6}$. The rate of oxidation of reduced Co I was followed by the fall in optical density at $340 \mathrm{~m} \mu$. in $1 \mathrm{~cm}$. quartz cells and was calculated from the linear portion of the curve. The rate of oxidation of reduced Co I was negligible without pyruvate. All determinations were made at room temp.

Oxidative phosphorylation. The technique involved the conversion of ATP formed into glucose 6-phosphate by hexokinase. The details of the medium used are given in Table 13. Inorganic phosphorus was determined by the method of Fiske \& Subbarow (1925) after deproteinization with a final concentration of $3 \%(w / v)$ TCA. The TCA $(0.5 \mathrm{ml} .60 \%, \mathrm{w} / \mathrm{v})$ was tipped from the side arm on the contents of the flasks at various times, followed later by $6.5 \mathrm{ml}$. water.

\section{RESULTS}

\section{Affinity for SH groups of glutathione and $B A L$}

Mercurials and tervalent arsenicals interact with enzymes requiring $\mathrm{SH}$ groups (Hellerman, 1937; Barron \& Singer, 1945; Peters, Sinclair \& Thompson, 1946; Stocken \& Thompson, 1946a). It was natural to suspect that compounds of tin would interfere with enzymes in a similar way.

Diethyltin dichloride. The reduction of the oxidation-reduction indicator 2:6-dichlorophenolindophenol by both GSH and BAL is completely prevented by $p$-chloromercuribenzoic acid at molecular quotients as low as 1.3 per molecule of SH compound (Table 1). Similarly, dye reduction by BAL is prevented by phenylarsenious acid and arsenious acid, whereas their affinity for the SH groups of glutathione is much less. Diethyltin dichloride reacts avidly with BAL, but only slightly with GSH. Thus the affinity of diethyltin dichloride for SH groups closely resembles that of phenylarsenious acid, arsenious acid and lewisite (Stocken \& Thompson, 1946a).
Triethyltin sulphate. Triethyltin sulphate has little affinity for either GSH or BAL (Table 1). In this respect it is unlike $p$-chloromercuribenzoic acid and diphenylchloroarsine, which have marked affinity for monothiols (Barron \& Singer, 1945; Lotspeich \& Peters, 1951).

\section{Experiments with rat-brain brei}

Diethyltin dichloride. Diethyltin dichloride $\left(10^{-4}-10^{-5} \mathrm{M}\right)$ prevents oxygen uptake of rat-brain brei when glucose, lactate and pyruvate are used as substrates. Determinations of pyruvate levels have been made in brain brei metabolizing lactate in the presence of arsenious acid, phenylarsenious acid and diethyltin dichloride. Diethyltin dichloride leads to an accumulation of pyruvate when the oxygen uptake is lowered and in this respect resembles arsenious acid and phenylarsenious acid (Table 2). Experiments have shown that with all

Table 2. Pyruvate levels in rat-brain brei oxidizing lactate in the presence of various inhibitors

Each flask contained lithium lactate $0.015 \mathrm{M}$, brei equivalent to $17 \mathrm{mg}$. wet wt. of original brain and inhibitor as indicated. The final volume was made up to $3.0 \mathrm{ml}$. with $0.1 \mathrm{M}$ phosphate buffer $\mathrm{pH} 7 \cdot 4$. The centre well contained $0.15 \mathrm{ml} .20 \%$ (w/v) $\mathrm{KOH}$ for $\mathrm{CO}_{2}$ absorption, except for the experiments with cyanide, when mixtures of $\mathrm{KOH}$ and KCN were used (Krebs, 1935). The gas phase was air and the temperature $37^{\circ}$. After $10 \mathrm{~min}$. equilibration readings were taken at 10,40 and $70 \mathrm{~min}$. At the end of the experiment $3.0 \mathrm{ml} .18 \%(\mathrm{w} / \mathrm{v})$ TCA were added to each flask and $3.0 \mathrm{ml}$. samples taken for the estimation of pyruvate. Values from control flasks without substrate, with and without inhibitor, were subtracted from the corresponding values for flasks containing lactate. The difference between the controls with and without lactate was approximately $23 \mu \mathrm{g}$. pyruvate/flask.
Concn. of inhibitor

$$
\text { (M) }
$$

Arsenious acid

$7.1 \times 10^{-6}$

$2.1 \times 10^{-5}$

$5.0 \times 10^{-5}$

Phenylarsenious acid

$9.9 \times 10^{-6}$

$3.0 \times 10^{-5}$

Triethyltin sulphate

$8.7 \times 10^{-6}$

$1.9 \times 10^{-5}$

$4.4 \times 10^{-5}$

$2.0 \times 10^{-4}$

Diethyltin dichloride

$1.4 \times 10^{-4}$

$2.7 \times 10^{-4}$

$8.1 \times 10^{-4}$

Cyanide

$3.0 \times 10^{-6}$

$3.0 \times 10^{-5}$
$\mathrm{O}_{2}$ uptake Pyruvate level (\% of control) (\% of control)

85

76

59

65

13

89

76

46

19

74

44

34

95

43
104

159

282

140

490

82

- 48

24

131

263

443

93 
Table 3. Effect of SH compounds upon the inhibition of pyruvate oxidation of rat-brain brei by various inhibitors

Each flask contained $0.01 \mathrm{~m}$ pyruvate. SH compounds and inhibitors were added as indicated and left 5 min. at room temp. before $1.0 \mathrm{ml}$. of brain brei (equivalent to $170 \mathrm{mg}$. wet weight of original brain) was added. The final volume was made up to $3.0 \mathrm{ml}$. with $0.1 \mathrm{M}$ phosphate buffer $\mathrm{pH} \mathrm{7.4}$. After warming up for $10 \mathrm{~min}$. to $37^{\circ}$ readings were taken at 10 , 40 and $70 \mathrm{~min}$. In each case a control flask without substrate was run and the value subtracted from the corresponding flask containing substrate. $R$ is the quotient of the molar concentration of SH compound/molar concentration of inhibitor.

\section{Concn. of $\mathrm{SH}$ compound} (M)

GSH, $5 \times 10^{-3}$

BAL, $3.8 \times 10^{-4}$

GSH, $5 \times 10^{-3}$

BAL, $3.8 \times 10^{-4}$

GSH, $5 \times 10^{-3}$

BAL, $3.8 \times 10^{-4}$
Concn. of inhibitor

(M)

Arsenious acid

$$
6 \times 10^{-5}
$$$$
6 \times 10^{-5}
$$

Diethyltin dichloride

$$
1.7 \times 10^{-4}
$$$$
1.7 \times 10^{-4}
$$

Triethyltin sulphate

$$
8.2 \times 10^{-5}
$$$$
6.5 \times 10^{-5}
$$

$\overbrace{\text { Inhibitor } \quad \mathrm{O}_{2} \text { uptake (\% of control) }}^{\begin{array}{c}\text { Inhibitor }+\mathrm{SH} \\ \text { compound }\end{array}}$

$84 \quad 18 \quad 20$

13

$\begin{array}{rrr}29 & 36 & 68 \\ 2 & 45 & 87\end{array}$

87

$\begin{array}{lll}61 & 18 & 27\end{array}$

three inhibitors this accumulation is prevented by BAL. Rat-brain brei is also protected by BAL from the inhibition of pyruvate oxidation by arsenious acid and diethyltin dichloride (Table 3). GSH, in higher concentration, is ineffective against arsenious acid inhibition and only partially effective against diethyltin dichloride inhibition.

Triethyltin sulphate. Triethyltin sulphate $\left(10^{-4}\right.$ $10^{-5} \mathrm{M}$ ) lowers oxygen uptake of rat-brain brei with glucose, lactate and pyruvate as substrates. In contrast to diethyltin dichloride with lactate as substrate, triethyltin sulphate lowers both oxygen uptake and pyruvate concentration (Table 2). Neither BAL nor GSH influences the lowered level of pyruvate or the inhibition of oxygen uptake with pyruvate as substrate (Table 3). A lowering of pyruvate level could theoretically be due to either an increased utilization or to a decreased production of pyruvate. The former is improbable with a lowered oxygen consumption. An inhibition of lactic dehydrogenase would produce less pyruvate, and anaerobic glycolysis would also be prevented. Little or no inhibition of anaerobic glycolysis is obtained at concentrations which will inhibit lactate oxidation in brain brei (Table 4). At concentrations over $10^{-3} \mathrm{M}$ complete inhibition is obtained. No explanation of this inhibition can be given, but it should be noted that diethyltin dichloride also inhibits at these concentrations and phenylarsenious acid produces considerable inhibition at $4 \times 10^{-5} \mathrm{M}$. It is clear that the lowering of pyruvate concentration cannot be due to a specific inhibition of lactic dehydrogenase, and this is confirmed by spectrophotometric measurements of the rate of reduction of Co I by a preparation of lactic dehydrogenase from rat liver (cf. Table 10).

Table 4. Effect of triethyltin sulphate upon anaerobic glycolysis by rat-brain dispersions

A rat brain (approx. 1.2 g.) was placed in a mortar surrounded by an ice and salt freezing mixture and ground until it had frozen to the sides of the mortar. Water (4.8 ml.) was added, forming a thick paste, followed by $6.0 \mathrm{ml}$. $0.02 \mathrm{M}$ phosphate buffer $\mathrm{pH} 7.4$ to give a $10 \%$ dispersion of brain, $\mathbf{0 . 3}$ ml. of which was added to a solution of the following substances, giving the final concentrations of $\mathrm{KHCO}_{3} 0.016 \mathrm{M},\left(\mathrm{NH}_{4}\right)_{2} \mathrm{HPO}_{4} 0.02 \mathrm{M}, \mathrm{MgCl}_{2} 0.007 \mathrm{M}$, nicotinamide $0.033 \mathrm{M}$, ATP $0.001 \mathrm{M}$, Co I $9.45 \times 10^{-4} \mathrm{M}$, glucose $0.024 \mathrm{M}$. The tubes were incubated for $30 \mathrm{~min}$. at $37^{\circ}, 5.8 \mathrm{ml}$. water and $1.2 \mathrm{ml}$. $60 \%(\mathrm{w} / \mathrm{v})$ TCA added. After centrifuging, lactic acid was determined in the supernatant. No difference in lactate production, using anaerobic or aerobic conditions, was found.

Concn. of triethyltin sulphate (M)

$$
\text { Nil }
$$

\section{$1.39 \times 10^{-6}$}

$6.96 \times 10^{-6}$

$3.48 \times 10^{-5}$

\begin{tabular}{|c|c|}
\hline \multicolumn{2}{|c|}{$\begin{array}{l}\text { Lactic acid produced } \\
\text { (mg./100 mg. wet wt. } \\
\text { brain/30 min.) }\end{array}$} \\
\hline Expt. 1 & Expt. 2 \\
\hline $\begin{array}{l}\mathbf{4} \cdot 90 \\
\mathbf{4} \cdot \mathbf{9 7} \\
\mathbf{4} \cdot \mathbf{6 7} \\
\mathbf{4} \cdot \mathbf{4 2} \\
\mathbf{4} \cdot \mathbf{5 0} \\
\mathbf{3} \cdot \mathbf{6 2} \\
\mathrm{Nil}\end{array}$ & $\begin{array}{l}5 \cdot 25 \\
5 \cdot 25 \\
5 \cdot 11 \\
4 \cdot 98 \\
4 \cdot 90 \\
4 \cdot 42 \\
0 \cdot 28\end{array}$ \\
\hline
\end{tabular}

$1.74 \times 10^{-4}$

$8.72 \times 10^{-4}$

$4.36 \times 10^{-3}$
Since lactic dehydrogenase is not inhibited by triethyltin sulphate, other components of the respiratory chain were considered. Inhibition of cytochrome oxidase by cyanide produces a lowering of pyruvate levels (Table 2). Triethyltin sulphate, unlike cyanide, does not inhibit succinate oxidation at the concentrations which inhibit the oxidation of lactate and pyruvate. At higher concentrations $\left(2 \times 10^{-4} \mathrm{M}\right)$ the effect varies with the concentration 
of substrate. With $0.06 \mathrm{M}$ succinate there is an inhibition of oxidation, while with $0.009 \mathrm{M}$ substrate there is invariably a stimulation. No detailed explanation can at present be given of these findings.

\section{Experiments with rat-liver mitochondria}

Diethyltin dichloride. The effect of inhibitors on the oxidation of various substrates by rat-liver mitochondria (Table 5) are given as the working range of inhibitor concentrations because it is difficult to obtain a precise amount of inhibition from experiment to experiment. With the exception of succinate, all the substrates of the tricarboxylic acid cycle are strongly inhibited by phenylarsenious acid and diethyltin dichloride. results are obtained with all three substrates (Table 6) estimating $\alpha$-keto acids during the early part of the experiments (3-12 min.). For these experiments the inhibitors were tipped in from the side arm to the actively metabolizing mitochondria. More inhibitor is required to produce a given amount of inhibition by this procedure than when fresh mitochondria are added directly to the inhibitor and substrate. It has been our experience that $\alpha$-keto acid levels are a better early index of enzyme inactivation than is oxygen uptake, and we have used this technique to examine the protective effect of SH compounds. The results in Table 7 make it clear that BAL prevents the $\alpha$-keto acid accumulation produced by both diethyltin dichloride and phenylarsenious acid, whereas GSH is ineffective.

Table 5. The inhibitory range of various substances upon the oxidation of substrates by rat-liver mitochondria

Each flask contained $3 \mathrm{ml}$. of a solution of AMP $0.00123 \mathrm{M}, \mathrm{MgSO}_{4} 0.0067 \mathrm{M}, \mathrm{KCl} 0.045 \mathrm{M}$, sodium phosphate pH 7.4 $0.0167 \mathrm{M}$, cytochrome $c 7.3 \times 10^{-6} \mathrm{M}$, substrate $0.01 \mathrm{M}$ ( $\beta$-hydroxybutyrate $0 \cdot 1 \mathrm{M}, p$-phenylenediamine $0.03 \mathrm{M}$ ), mitochondria $(0.5 \mathrm{ml}$.$) in 0.9 \%(\mathrm{w} / \mathrm{v}) \mathrm{KCl}$ and various inhibitors. Mitochondria were added to the above components at room temperature, warmed to $37^{\circ}$ for $10 \mathrm{~min}$. and readings taken for 10-70 min. pI = - log (molar concentration of inhibitor). Where it was not possible to produce complete inhibition, the inhibition obtained with the concentration of inhibitor stated is given in brackets.

\begin{tabular}{|c|c|c|c|c|}
\hline & \multicolumn{4}{|c|}{ Inhibitors } \\
\hline & $\begin{array}{c}\text { Phenylarsenious } \\
\text { acid }\end{array}$ & $\begin{array}{l}\text { Diethyltin } \\
\text { dichloride }\end{array}$ & $\begin{array}{l}\text { Diphenyl- } \\
\text { chloroarsine }\end{array}$ & $\begin{array}{l}\text { Triethyltin } \\
\text { sulphate }\end{array}$ \\
\hline Substrate & \multicolumn{4}{|l|}{ 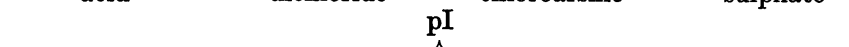 } \\
\hline L-Malate & $6 \cdot 0-6 \cdot 5$ & $4 \cdot 5-5 \cdot 5$ & $4 \cdot 5-5 \cdot 4$ & $4 \cdot 7-5 \cdot 7$ \\
\hline Citrate & $5 \cdot 3-6 \cdot 0$ & $3 \cdot 8-4 \cdot 8$ & $5 \cdot 0-5 \cdot 7$ & $4 \cdot 5-5 \cdot 5$ \\
\hline$\alpha$-Oxoglutarate & $5 \cdot 7-6 \cdot 5$ & $4 \cdot 3-5 \cdot 3$ & $4 \cdot 7-5 \cdot 4$ & $4 \cdot 2-5 \cdot 2$ \\
\hline Succinate & $4.5(25 \%)$ & $3.9(25 \%)$ & $4 \cdot 2(25 \%)$ & $3.9(40 \%)$ \\
\hline Pyruvate & $6 \cdot 0-7 \cdot 0$ & $4 \cdot 5-5 \cdot 5$ & $4 \cdot 4-5 \cdot 4$ & $4 \cdot 2-5 \cdot 2$ \\
\hline L-Glutamate & $6 \cdot 0-6 \cdot 5$ & $4 \cdot 3-5 \cdot 3$ & $4 \cdot 4-5 \cdot 1$ & $4 \cdot 5-5 \cdot 5$ \\
\hline$p$-Phenylenediamine & $3 \cdot 5(20 \%)$ & $3.9(20 \%)$ & - & $3.9(0 \%)$ \\
\hline$\beta$-Hydroxybutrate & $4 \cdot 4-5 \cdot 0$ & - & - & $4 \cdot 5-5 \cdot 5$ \\
\hline
\end{tabular}

The oxidation of L-glutamate is also inhibited, but the oxidation of succinate is only slightly inhibited. With ferricyanide as an electron acceptor instead of oxygen, diethyltin dichloride and phenylarsenious acid prevent the oxidation of L-malate, citrate and $\alpha$-oxoglutarate. The concentrations of diethyltin dichloride necessary for inhibition under these conditions are less than when measuring oxygen uptake, whereas phenylarsenious acid is equally effective for both procedures. The oxidation of succinate was much less affected by both diethyltin dichloride and phenylarsenious acid than the oxidation of the other three substrates.

An examination has been made of the influence of these inhibitors on the $\alpha$-keto acid concentrations when citrate, L-glutamate and L-malate are used as substrates. With citrate, both diethyltin dichloride and phenylarsenious acid produce a continuous rise in $\alpha$-keto acid concentration (Fig. 1). Similar
Triethyltin sulphate. Triethyltin sulphate and diphenylchloroarsine inhibit the oxidation of $L$ glutamate and all the tricarboxylic acid cycle substrates except succinate (Table 5). Succinate oxidation is only slightly inhibited by higher concentrations of both inhibitors. Triethyltin sulphate inhibits $\beta$-hydroxybutyrate oxidation at the same concentration as it inhibits the substrates of the tricarboxylic acid cycle. With citrate as a substrate there is a primary depression of $\alpha$-keto acid levels, followed later (30-70 min.) by a slight accumulation (Fig. 1). The results in Table 6 show that triethyltin sulphate consistently produces an early depression of $\alpha$-keto acid levels when either L-malate, Lglutamate or citrate is used as substrate. Diphenylchloroarsine produces some accumulation with $\mathrm{L}$ malate and citrate, but has no effect on the $\alpha$-keto acid levels with L-glutamate as substrate. Neither BAL nor GSH influences the fall in $\alpha$-keto acid level 
produced by triethyltin sulphate with citrate as substrate (Table 7).

It is clear that triethyltin sulphate is a potent inhibitor of oxidation of tricarboxylic acid cycle substrates (except succinate) by rat-liver mitochondria. With lactate oxidation by rat-brain brei it produces a lowering of pyruvate concentration, and similarly with the oxidation of L-malate, Lglutamate and citrate it produces a primary lowering of $\alpha$-keto acid levels. Such symptoms could be produced by a block at some stage in the respiratory chain. Triethyltin sulphate does not

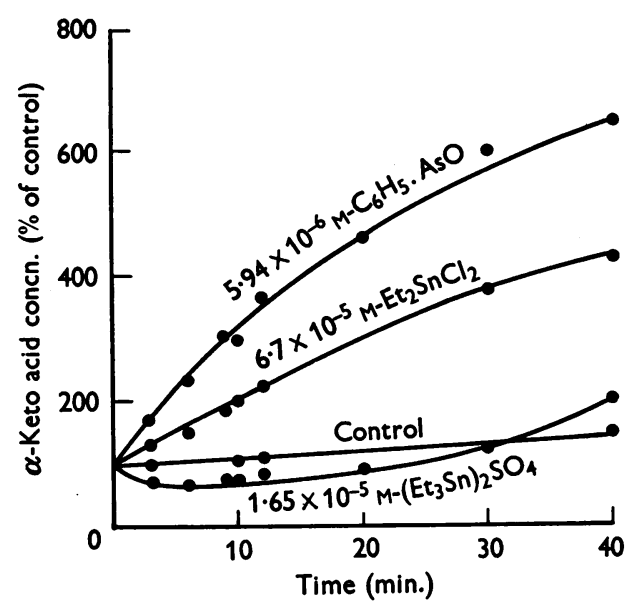

Fig. 1. $\alpha$-Keto acid concentration at various times after treatment of rat-liver mitochondria oxidizing citrate with various inhibitors. The components of the flask are as given in Table 5. Mitochondria equivalent to $167 \mathrm{mg}$. wet wt. of original liver were added at room temp., warmed to $37^{\circ}$ for $10 \mathrm{~min}$. and the inhibitor or water tipped in from the side arm. At various times $3 \mathrm{ml}$. $18 \%(w / v)$ TCA were added and the total $\alpha$-keto acids determined. The inhibition of $\mathrm{O}_{2}$ uptake for all three inhibitors was 23-27\%. The ratios of optical densities at 420 and $520 \mathrm{~m} \mu$. indicated that $68-75 \%$ of the keto acids were $\alpha$-oxoglutarate.

inhibit cytochrome oxidase, determined by using $p$-phenylenediamine as substrate (Table 5), and this is confirmed by the measurements of reduced cytochrome $c$ in the flasks at the end of a manometric experiment using L-glutamate as substrate (Table 8). More cytochrome $c$ was always found in the oxidized state than in the control, and triethyltin sulphate lowered the amount of reduced cytochrome $c$ found in the presence of cyanide. Similar results have been obtained with L-malate as substrate. The results given in Table 9 show that the inhibition of succinate oxidation (Table 5) was due to depletion of substrate. In the presence of triethyltin sulphate 1 atom of oxygen is consumed for every mol. of succinate, whereas in the control
7 atoms of oxygen are used. For the experiments described in Table 5, $30 \mu \mathrm{mol}$. of succinate per flask were used. This amount of succinate would have been completely oxidized in the presence of triethyltin sulphate, whereas in the controls only a small proportion would have been removed. In our experiments using ferricyanide as electron acceptor we found no inhibition of succinate oxidation. This is explained by the short time of the experiment (35 min.) and the use of less mitochondria, because there is an evolution of 2 moles of $\mathrm{CO}_{2}$ for every atom

Table 6. $\alpha$-Keto acid levels produced by rat-liver mitochondria with citrate, L-malate and L-glutamate as substrates in the prescnce of various inhibitors

The components of the flasks were as given in Table 5 . Mitochondria (equivalent to $167 \mathrm{mg}$. wet wt. of original liver) were added to the flasks at room temp. They were warmed to $37^{\circ}$ for $10 \mathrm{~min}$. and the inhibitor or water was tipped in from the side arm. After the times indicated $3 \mathrm{ml} .18 \%(w / v)$ TCA were added and total $\alpha$-keto acids determined.

$\overbrace{3 \quad \begin{array}{c}6 \\ \alpha-K e t o \text { acid concentration } \\ (\% \text { of control at } 3 \text { min.) }\end{array}}^{\text {Time with inhibitor (min.) }} \begin{gathered}12 \text { min. } \\ \begin{array}{c}\text { Control } \\ \text { Cfter }\end{array}\end{gathered}$

Substrate

Phenylarsenious acid, $5 \cdot 9 \times 10^{-6} \mathrm{M}$

\begin{tabular}{|c|c|c|c|c|c|}
\hline $\begin{array}{l}\text { L-Malate } \\
\text { L-Glutamate } \\
\text { Citrate }\end{array}$ & $\begin{array}{l}176 \\
240 \\
160\end{array}$ & $\begin{array}{l}240 \\
303 \\
204\end{array}$ & $\begin{array}{l}310 \\
386 \\
253\end{array}$ & $\begin{array}{l}380 \\
396 \\
288\end{array}$ & $\begin{array}{l}\overline{122} \\
120\end{array}$ \\
\hline \multicolumn{6}{|c|}{ Diethyltin dichloride, $6.7 \times 10^{-5} \mathrm{M}$} \\
\hline $\begin{array}{l}\text { L-Malate } \\
\text { L-Glutamate } \\
\text { Citrate }\end{array}$ & $\begin{array}{l}124 \\
200 \\
144\end{array}$ & $\begin{array}{l}134 \\
277 \\
159\end{array}$ & $\begin{array}{l}159 \\
295 \\
202\end{array}$ & $\begin{array}{l}185 \\
317 \\
248\end{array}$ & $\begin{array}{r}89 \\
115 \\
121\end{array}$ \\
\hline \multicolumn{6}{|c|}{ Diphenylchloroarsine, $6.7 \times 10^{-5} \mathrm{M}$} \\
\hline $\begin{array}{l}\text { L-Malate } \\
\text { L-Glutamate } \\
\text { Citrate }\end{array}$ & $\begin{array}{l}134 \\
125 \\
123\end{array}$ & $\begin{array}{l}164 \\
120 \\
134\end{array}$ & $\begin{array}{l}150 \\
107 \\
-\end{array}$ & $\begin{array}{l}187 \\
105 \\
158\end{array}$ & $\begin{array}{r}97 \\
118 \\
127\end{array}$ \\
\hline \multicolumn{6}{|c|}{ Triethyltin sulphate, $1.6 \times 10^{-5} \mathrm{M}$} \\
\hline $\begin{array}{l}\text { L-Malate } \\
\text { L-Glutamate } \\
\text { Citrate }\end{array}$ & $\begin{array}{l}62 \\
80 \\
71\end{array}$ & $\frac{62}{67}$ & $\begin{array}{l}59 \\
88 \\
75\end{array}$ & $\begin{array}{l}70 \\
99 \\
85\end{array}$ & $\begin{array}{l}104 \\
121 \\
101\end{array}$ \\
\hline
\end{tabular}

of oxygen. It is concluded from these experiments: that succinic oxidase is not inhibited by triethyltin sulphate. Therefore, on the basis of current views. (Keilin \& Slater, 1953), the respiratory chain from oxygen down as far as the succinic-cytochrome $c$. factor (Slater, 1949; Clark, Neufeld, Widmer \& Stotz, 1954) is functional in the presence of triethyltin sulphate. The remaining components down. to and including the dehydrogenases have been examined. Co I-cytochrome $c$ reductase has been determined by the rate of reduction of cytochrome $c$ in the presence of reduced Co $I$. This rate is not. altered by $5 \times 10^{-4} \mathrm{M}$ triethyltin sulphate. The, 
activity of the lactic, L-malic or L-glutamic dehydrogenases of rat-liver extract or the L-malic or Lglutamic dehydrogenases of rat-liver mitochondria is not affected by $4 \times 10^{-4} \mathrm{M}$ triethyltin sulphate (Table 10). In agreement with the results of Christie \& Judah (1953) we find that treatment of mitochondria with water greatly increases the rate of Co I reduction with $\mathrm{L}$-malate or L-glutamate as substrate. This increased activity is not inhibited by triethyltin sulphate.

Table 7. Prevention by SH compounds of the accumulation of $\alpha$-keto acids by rat-liver mitochondria oxidizing citrate in the presence of various inhibitors

Each flask contained $3 \mathrm{ml}$. of a solution of AMP $0.00123 \mathrm{M}$,

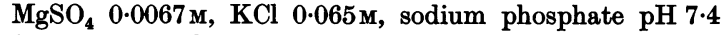
$0.0167 \mathrm{M}$, cytochrome $c 7.3 \times 10^{-6} \mathrm{M}$, sodium citrate $0.01 \mathrm{M}$, mitochondria equivalent to $333 \mathrm{mg}$. wet wt. of original liver. Mitochondria were added at room temp. to the solution of these components together with the SH compound, warmed to $37^{\circ}$ for $2 \mathrm{~min}$., and the inhibitor or water was tipped in from the side arm. After 6 min. at $37^{\circ}$ $3 \mathrm{ml} .18 \%(\mathrm{w} / \mathrm{v})$ TCA were added and the total $\alpha$-keto acids determined. The controls contained approximately $65 \mu \mathrm{g}$. $\alpha$-oxoglutarate. The quotient of the optical densities $420 \mathrm{~m} \mu$. $/ 520 \mathrm{~m} \mu$. was $2 \cdot 06 \pm 0 \cdot 013$. $R$ is the quotient of the molar concentration of SH compound/molar concentration of the inhibitor.

\begin{tabular}{|c|c|c|c|c|}
\hline 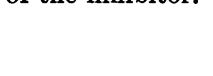 & & \multicolumn{3}{|c|}{$\begin{array}{l}\alpha-\text { Keto acid concentration } \\
(\% \text { of control })\end{array}$} \\
\hline $\begin{array}{l}\text { Concn. of } \\
\text { SH compound } \\
(\mathbf{M})\end{array}$ & $R$ & $\begin{array}{c}\text { SH } \\
\text { compound }\end{array}$ & Inhibitor & $\begin{array}{c}\mathrm{SH} \\
\text { compound } \\
+ \text { inhibitor }\end{array}$ \\
\hline \multicolumn{5}{|c|}{ Phenylarsenious acid, $5.9 \times 10^{-6} \mathrm{M}$} \\
\hline GSH, $1.23 \times 10^{-4}$ & $20 \cdot 8$ & 102 & 260 & 310 \\
\hline BAL, $6.9 \times 10^{-5}$ & $11 \cdot 7$ & 88 & 294 & 89 \\
\hline \multicolumn{5}{|c|}{ Diethyltin dichloride, $7 \cdot 8 \times 10^{-5} \mathrm{M}$} \\
\hline GSH, $1 \cdot 61 \times 10^{-3}$ & $20 \cdot 7$ & 66 & 202 & 152 \\
\hline BAL, $8 \cdot 6 \times 10^{-4}$ & $11 \cdot 0$ & 113 & 157 & 113 \\
\hline \multicolumn{5}{|c|}{ Triethyltin sulphate, $3.3 \times 10^{-5} \mathrm{M}$} \\
\hline GSH, $6 \cdot 6 \times 10^{-4}$ & $20 \cdot 0$ & 86 & 54 & 53 \\
\hline BAL, $3 \cdot 3 \times 10^{-4}$ & $10 \cdot 0$ & 116 & 56 & 59 \\
\hline
\end{tabular}

Since both the triethylstannyl group and oxidized Co I are positively-charged ions the possibility of competition was considered. The equilibrium point of the reaction lactate $\rightleftharpoons$ pyruvate at $\mathrm{pH} 7 \cdot 4$ is very much in favour of lactate formation and therefore minimal concentrations of Co I may be used $\left(1 \times 10^{-4} \mathrm{M}\right)$. Triethyltin sulphate at 100 times this concentration has no effect upon the rate of oxidation of reduced Co I by pyruvate in the presence of rat-liver extract. It appears therefore that the respiratory chain is unaffected by triethyltin sulphate. This conclusion has been deduced from experiments using techniques very different from the manometric methods. However, experiments with $\beta$-hydroxybutyrate, using the mano-

Table 8. The levels of reduced cytochrome c produced by rat-liver mitochondria oxidizing L-glutamate in the presence of triethyltin sulphate and cyanide

The components of the flasks were as given in Table 5 except for an increased cytochrome $c$ concentration, $5 \cdot 1 \times 10^{-4} \mathrm{M}$. For the flasks containing cyanide, $\mathrm{CO}_{2}$ was absorbed by a mixture of $10 \mathrm{ml} . \mathrm{N}-\mathrm{KCN}$ and $1 \mathrm{ml} . \mathrm{N} \cdot \mathrm{KOH}$ (Krebs, 1935). $\mathrm{O}_{2}$ uptake was measured from 10 to $25 \mathrm{~min}$. The flasks were then quickly cooled in ice and the contents centrifuged at $0^{\circ}$ at $10000 \mathrm{~g}$ for $10 \mathrm{~min}$. The optical density of the clear supernatant was determined in $1 \mathrm{~cm}$. cells at $549 \mathrm{~m} \mu$. The concentration of cytochrome $c$ was determined by the optical density at $549 \mathrm{~m} \mu$. after the addition of 1 drop $10 \%(w / v) \mathrm{K}_{3} \mathrm{Fe}(\mathrm{CN})_{6}$. This was done in preference to reduction with $\mathrm{Na}_{2} \mathrm{~S}_{2} \mathrm{O}_{4}$, since in the presence of triethyltin sulphate cloudiness was produced.

\begin{tabular}{|c|c|c|}
\hline Additions & $\begin{array}{c}\mathrm{O}_{2} \text { uptake } \\
(\mu \mathrm{l} ., \\
\text { 10-25 min.) }\end{array}$ & $\begin{array}{c}\text { Reduced } \\
\text { cytochrome } \\
\text { (\% of total) }\end{array}$ \\
\hline Nil & 85 & 10 \\
\hline $\mathrm{KCN}, 1 \times 10^{-3} \mathrm{M}$ & 8 & 58 \\
\hline $\begin{array}{l}\text { Triethyltin sulphate, } \\
9 \cdot 9 \times 10^{-4} \mathrm{M}\end{array}$ & 0 & 5 \\
\hline $\begin{array}{l}\text { KCN, } 1 \times 10^{-3} \mathrm{M} \\
+ \text { Triethyltin sulphate, } \\
9.9 \times 10^{-4} \mathrm{M}\end{array}$ & $\mathbf{0}$ & 27 \\
\hline
\end{tabular}

Table 9. The oxidation of succinate by rat-liver mitochondria in the presence of triethyltin sulphate

The components in the flask were as given in Table 7 with succinate in the amounts stated and triethyltin sulphate $2.6 \times 10^{-4} \mathrm{M}$ where indicated. Mitochondria (equivalent to $333 \mathrm{mg}$. wet wt. of original liver) were added at room temp. to a solution of all components, the flasks warmed to $37^{\circ}$ and readings taken from 5 min. until $\mathrm{O}_{2}$ uptake ceased. For the control experiments the $\mathrm{O}_{2}$ uptake was extrapolated graphically to zero time and corrected for $\mathrm{O}_{2}$ uptake obtained without substrate. $\mathrm{O}_{2}$ uptake had almost ceased by $\mathrm{l} \mathrm{hr}$. For the experiments in the presence of triethyltin sulphate the $\mathrm{O}_{2}$ uptake for the first amount of succinate was extrapolated graphically to zero time. The second amount of succinate was tipped in from the side arm when $\mathrm{O}_{2}$ uptake had ceased (30 min.). Each value is the mean of two results.

\begin{tabular}{|c|c|c|c|}
\hline System & $\begin{array}{l}\text { Succinate added } \\
(\mu \text {-moles })\end{array}$ & $\begin{array}{c}\mathrm{O}_{2} \text { uptake } \\
(\boldsymbol{\mu} \text {-atom })\end{array}$ & $\frac{\mu \text {-atom } \mathrm{O}_{2}}{\begin{array}{c}\mu \text {-mole } \\
\text { succinate }\end{array}}$ \\
\hline Control & $5 \cdot 62$ & $39 \cdot 6$ & $7 \cdot 05$ \\
\hline $\begin{array}{l}\text { Triethyltin sulphate, } 2.6 \times 10^{-4} \mathrm{M} \\
\text { Triethyltin sulphate, } 2.6 \times 10^{-4} \mathrm{M}\end{array}$ & $\begin{array}{l}22 \cdot 5 \text { (1st addition) } \\
22 \cdot 5 \text { (2nd addition) }\end{array}$ & $\begin{array}{l}25 \cdot 0 \\
26 \cdot 4\end{array}$ & $\begin{array}{l}1 \cdot 11 \\
1 \cdot 17\end{array}$ \\
\hline No AMP & 22.5 (2nd addition) & $24 \cdot 5$ & $1 \cdot 08$ \\
\hline
\end{tabular}


metric technique, have shown that the same conclusion is valid.

Provided that Co $I$ is added, $\beta$-hydroxybutyrate can be oxidized by rat-liver mitochondria, while phosphorylation (measured by the rate of incorporation of ${ }^{32} \mathrm{P}$ into esterified phosphorus) is absent (Lehninger, 1949). The oxidation of $\beta$ hydroxybutyrate is a one-step oxidation, the oxygen consumed being equivalent to the acetoacetate formed (Lehninger, 1949; Walker, 1954).

Table 10. Effect of triethyltin sulphate upon dehydrogenases of rat-liver extract and rat-liver mitochondria

Each solution $(4 \mathrm{ml}$.) contained the following constituents; sodium phosphate $0.1 \mathrm{M}$, substrate $3.75 \times 10^{-2} \mathrm{M}$, KCN $2.2 \times 10^{-4} \mathrm{M}$, Co I $2.7 \times 10^{-3} \mathrm{M}$, and $3.96 \times 10^{-4} \mathrm{M}$ triethyltin sulphate where indicated. An extract of acetone-dried rat liver was prepared by homogenizing $2 \mathrm{~g}$.

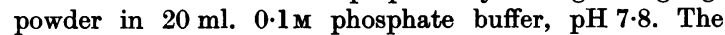
suspension was centrifuged $(5000 \mathrm{~g})$ for $20 \mathrm{~min}$. at $0^{\circ}$. The almost clear yellow extract was diluted with water and $0.5 \mathrm{ml}$. of a 50 -fold dilution used for each determination. Rat-liver mitochondria suspended in $0.9 \%(\mathrm{w} / \mathrm{v}) \mathrm{KCl}$ were centrifuged at $2500 \mathrm{~g}$ for $5 \mathrm{~min}$. and suspended in either ice-cold $0.9 \% \mathrm{KCl}$ or water to give a solution equivalent to $83 \mathrm{mg}$. wet wt. of original liver $/ \mathrm{ml}$. Readings have been taken at room temp. $\left(18-20^{\circ}\right)$ in $1 \mathrm{~cm}$. quartz cells, using the Unicam S.P. 650 quartz spectrophotometer. Control tube contained no Co I. Blank reduction rates were determined without substrate. Rates of reduction have been calculated from the time taken for the optical density at $340 \mathrm{~m} \mu$. to rise from 0.35 to 0.45 equivalent to the reduction of $0.0644 \mu$-mole Co $\mathrm{I} / 4 \mathrm{ml}$. The $\mathrm{pH}$ was checked at end of the experiments with a glass electrode.

\begin{tabular}{|c|c|c|c|}
\hline & & \multicolumn{2}{|c|}{ Co I reduction } \\
\hline Substrate & $\mathrm{pH}$ & Control & $\begin{array}{l}\text { With } \\
\text { triethyltin } \\
\text { sulphate }\end{array}$ \\
\hline liver extract & & \multicolumn{2}{|c|}{$\begin{array}{c}(\mu \text {-mole } / 100 \mathrm{mg} . \text { acetone } \\
\text { powder } / \mathrm{hr} .)\end{array}$} \\
\hline Lactate & $7 \cdot 56$ & 500 & 500 \\
\hline L-Glutamate & $7 \cdot 56$ & 140 & 140 \\
\hline L-Malate & $7 \cdot 81$ & 270 & 270 \\
\hline
\end{tabular}

$\mathrm{KCl}$-suspended mitochondria $\quad(\mu$-mole/g. original liver/hr.)

$\begin{array}{llll}\text { L-Glutamate } & 7 \cdot 56 & 15 & 24 \\ \text { L-Malate } & 7 \cdot 81 & 13 & 18\end{array}$

Water-suspended mitochondria

$\begin{array}{llll}\text { L-Glutamate } & 7 \cdot 56 & 130 & 121 \\ \text { L-Malate } & 7 \cdot 81 & 127 & 140\end{array}$

If Co I is present oxygen uptake is normal for $15 \mathrm{~min}$. without the addition of either AMP or magnesium. Under these conditions $4 \times 10^{-5} \mathrm{M}$ triethyltin sulphate has little or no effect upon the oxidation of $\beta$-hydroxybutyrate (Table 11). The protective effect of Co I during the early part of the experiment diminishes later (Table 12, Fig. 2).
Co I also partially prevents the inhibition of L-malate oxidation by triethyltin sulphate (Table 12). This effect diminishes rapidly, and Co $I$ is not as effective with L-malate as with $\beta$-hydroxybutyrate as substrate. The respiratory chain in the early periods of the experiment in the presence of Co $I$ is functional and the inhibition produced later is probably due to some other process.

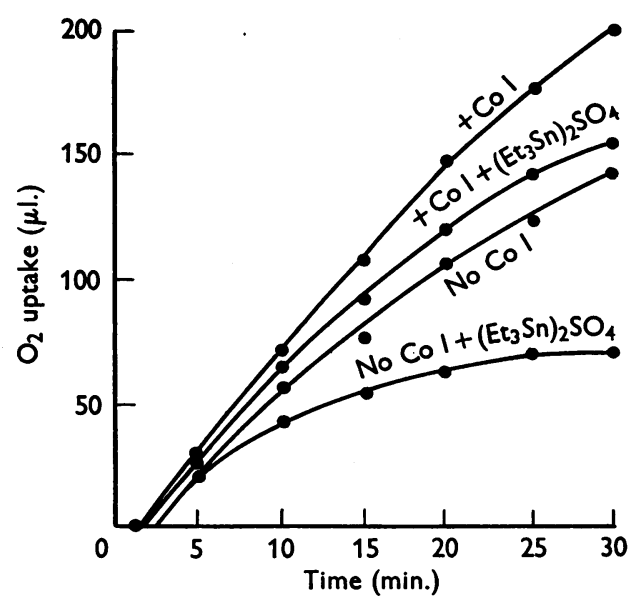

Fig. 2. The effect of Co I on the oxidation of $\beta$-hydroxybutyrate by rat-liver mitochondria with and without triethyltin sulphate. The components of the flasks were as given in Table 12. The substrate $(0 \cdot 1 \mathrm{M})$ and triethyltin sulphate $\left(2 \cdot 2 \times 10^{-5} \mathrm{M}\right)$ were in the side arm. Mitochondria (equivalent to $250 \mathrm{mg}$. wet wt. of original liver tissue) were added to the ice-cold contents of the flasks, warmed to $37^{\circ}$ for 5 min., a zero reading taken and the substrate and inhibitor tipped in at $1 \mathrm{~min}$.

Table 11. Effect of $A M P$, magnesium, Co $I$ and triethyltin sulphate on the oxidation of $\beta$-hydroxybutyrate by rat-liver mitochondria

Each flask contained $3 \mathrm{ml}$. of a solution of $\mathrm{KCl}$ $0.045 \mathrm{M}$, sodium phosphate $\mathrm{pH} 7.40 .0167 \mathrm{M}$, cytochrome $c$ $7 \cdot 3 \times 10^{-6} \mathrm{M}$, nicotinamide $0.02 \mathrm{M}$ and mitochondria equivalent to $250 \mathrm{mg}$. wet wt. of original liver, $\beta$-hydroxybutyrate $0.1 \mathrm{M}$, Co I $3.66 \times 10^{-4} \mathrm{M}$ and, where indicated, AMP $0.00123 \mathrm{M}, \mathrm{MgSO}_{4} 0.0067 \mathrm{M}$ and triethyltin sulphate $4.4 \times 10^{-5} \mathrm{M}$. The substrate and inhibitor were in the side arm. Mitochondria were added at room temp. to the solution of the above components and, after warming for $5 \mathrm{~min}$. to $37^{\circ}$, the substrate and inhibitor tipped in from the side arm and readings taken every 5 min.

\begin{tabular}{|c|c|}
\hline \multicolumn{2}{|c|}{$\mathrm{O}_{2}$ uptake $(\mu 1 ., 5-15 \mathrm{~min})}$. \\
\hline Control & $\begin{array}{l}\text { With triethyltin } \\
\text { sulphate }\end{array}$ \\
\hline $\begin{array}{l}69 \\
55 \\
68 \\
70\end{array}$ & $\begin{array}{l}57 \\
51 \\
74 \\
69\end{array}$ \\
\hline
\end{tabular}


The maintenance of a low water content and a higher potassium concentration within mitochondria is a process which requires metabolism or 'high-energy' phosphates (Macfarlane \& Spencer, 1953; Price \& Davies, 1954; Brenner-Holzach \&

Table 12. Effect of Co I on the oxidation of $\beta$-hydroxybutyrate and L-malate by rat-liver mitochondria in the presence of triethyltin sulphate

Each flask contained $3 \mathrm{ml}$. of a solution of AMP $0.00123 \mathrm{M}, \mathrm{MgSO}_{4} 0.0067 \mathrm{M}, \mathrm{KCl} 0.045 \mathrm{M}$, sodium phosphate pH $7.40 .0167 \mathrm{M}$, cytochrome $c 7.3 \times 10^{-6} \mathrm{M}$, nicotinamide $0.02 \mathrm{M}$ and mitochondria equivalent to $167 \mathrm{mg}$. wet wt. of original liver. Where indicated, Co I $3.66 \times 10^{-4} \mathrm{M}, \beta$ hydroxybutyrate $0.1 \mathrm{M}$ and L-malate $0.01 \mathrm{~m}$ were added. Mitochondria were added to the solution of the above components at room temp. warmed to $37^{\circ}$ for $10 \mathrm{~min}$. and readings taken every $5 \mathrm{~min}$.

\begin{tabular}{|c|c|c|c|c|}
\hline \multirow{3}{*}{$\begin{array}{l}\text { Concn. of } \\
\text { triethyltin } \\
\text { sulphate } \\
\text { (M) }\end{array}$} & \multicolumn{4}{|c|}{$\mathrm{O}_{2}$ uptake $(\mu \mathrm{l})}$. \\
\hline & \multicolumn{2}{|c|}{$10-20 \mathrm{~min}}$. & \multicolumn{2}{|c|}{ 20-30 min. } \\
\hline & No Co I & With Co I & No Co I & With Co I \\
\hline & \multicolumn{4}{|c|}{$\beta$-Hydroxybutyrate oxidation } \\
\hline $\begin{array}{l}\text { Nil } \\
1.32 \times 10^{-4} \\
4.4 \times 10^{-5} \\
1.47 \times 10^{-5} \\
4.9 \times 10^{-6}\end{array}$ & $\begin{array}{r}60 \\
3 \\
\mathbf{3} \\
\mathbf{3 9} \\
58\end{array}$ & $\begin{array}{l}61 \\
27 \\
45 \\
57 \\
62\end{array}$ & $\begin{array}{r}41 \\
0 \\
0 \\
24 \\
28\end{array}$ & $\begin{array}{l}45 \\
11 \\
25 \\
32 \\
42\end{array}$ \\
\hline \multicolumn{5}{|c|}{ L-Malate oxidation } \\
\hline $\begin{array}{l}\text { Nil } \\
1.32 \times 10^{-4} \\
4.4 \times 10^{-5} \\
1.47 \times 10^{-5}\end{array}$ & $\begin{array}{l}57 \\
10 \\
10 \\
33\end{array}$ & $\begin{array}{l}71 \\
30 \\
29 \\
56\end{array}$ & $\begin{array}{r}52 \\
11 \\
2 \\
24\end{array}$ & $\begin{array}{l}68 \\
11 \\
21 \\
30\end{array}$ \\
\hline
\end{tabular}

Raaflaub, 1954). In a medium containing magnesium sulphate, potassium chloride, sodium phosphate pH 7.4 and cytochrome $c$, but without AMP, succinate is the only acid of the tricarboxylic acid cycle oxidized. The oxidation of pyruvate, citrate, $\alpha$-oxoglutarate, $\mathrm{L}$-glutamate and L-malate is entirely prevented, and for the oxidation of $1 \mathrm{~mol}$. succinate only 1 atom oxygen is consumed (Table 9). In this respect the effect of triethyltin sulphate resembles a system without a phosphate acceptor. Triethyltin sulphate could produce the biochemical symptoms previously described, by preventing the formation of ATP, and the results in Table 13 show that it is a potent inhibitor of the phosphorylation processes associated with the oxidation of $\beta$-hydroxybutyrate, citrate and succinate. The inhibition of inorganic phosphate uptake is always more than the inhibition of oxygen uptake. Inhibition of oxidation is therefore a secondary process. Triethyltin sulphate is as efficient an inhibitor of phosphorylation as 2:4dinitrophenol.

\section{DISCUSSION}

Diethyltin dichloride and triethyltin sulphate influence the biochemical mechanisms of rat-brain brei and rat-liver mitochondria in different ways. Phenylarsenious acid and diphenylchloroarsine are also dissimilar in this respect (Peters, 1952). Diethyltin dichloride and phenylarsenious acid produce a similar response, but the biochemical symptoms produced by triethyltin sulphate and diphenylchloroarsine are not identical. Previous

Table 13. The inhibition of oxidative phosphorylation by triethyltin sulphate and 2:4-dinitrophenol

Each flask contained $3.0 \mathrm{ml}$. of a solution of AMP $0.00123 \mathrm{M}, \mathrm{MgSO}_{4} 0.0067 \mathrm{M}, \mathrm{KCl} 0.045 \mathrm{M}$, cytochrome $c 7.3 \times 10^{-6} \mathrm{M}$, sodium phosphate buffer pH 7.4 $0.0167 \mathrm{M}$, NaF 0.008 , sodium glycylglycine buffer pH 7.4 $0.0165 \mathrm{~m}$, glucose $0.0074 \mathrm{M}$, yeast hexokinase 100 units and mitochondria equivalent to $250 \mathrm{mg}$. wet wt. of original liver. Where indicated, $\beta$-hydroxybutyrate $0.1 \mathrm{M}$ and succinate and citrate $0.01 \mathrm{~m}$ were used. The mitochondria were added to the solution of the above components at $0^{\circ}$, warmed to $37^{\circ}$ for $5 \mathrm{~min}$. and readings taken at 5, 10 and $15 \mathrm{~min}$. Inorganic phosphorus was determined at $5 \mathrm{~min}$. on a duplicate set of flasks. TCA $(0.5 \mathrm{ml} ., 60 \%, \mathrm{w} / \mathrm{v})$ was tipped in from the side arm for deproteinization. The results are expressed as a percentage of the control $\mathrm{O}_{2}$ or inorganic phosphorus uptake for the 5-15 min. period. The concentrations of triethyltin sulphate used do not inhibit hexokinase.

\begin{tabular}{|c|c|c|c|c|c|}
\hline $\begin{array}{l}\text { Concn. of } \\
\text { triethyltin sulphate } \\
\text { (M) }\end{array}$ & $\begin{array}{c}\mathrm{O}_{2} \text { uptake } \\
\text { (\% of control) }\end{array}$ & $\begin{array}{l}\text { Inorganic } P \\
\text { uptake } \\
(\% \text { of control) }\end{array}$ & $\begin{array}{l}\text { Concn. of } \\
\text { 2:4-dinitrophenol } \\
\text { (M) }\end{array}$ & $\begin{array}{c}\mathrm{O}_{2} \text { uptake } \\
\text { (\% of control) }\end{array}$ & $\begin{array}{l}\text { Inorganic } P \\
\text { uptake } \\
\text { (\% of control) }\end{array}$ \\
\hline \multicolumn{6}{|c|}{$\beta$-Hydroxybutyrate oxidation } \\
\hline $\begin{array}{l}5 \cdot 3 \times 10^{-5} \\
1 \cdot 76 \times 10^{-5} \\
5 \cdot 8 \times 10^{-6}\end{array}$ & $\begin{array}{r}42 \\
96 \\
100\end{array}$ & $\begin{array}{r}0 \\
31 \\
88\end{array}$ & $\begin{array}{l}4 \cdot 15 \times 10^{-5} \\
1 \cdot 4 \times 10^{-5} \\
-\end{array}$ & $\begin{array}{r}100 \\
100 \\
-\end{array}$ & $\begin{array}{l}13 \\
52 \\
-\end{array}$ \\
\hline \multicolumn{6}{|c|}{ Succinate oxidation } \\
\hline $\begin{array}{l}5 \cdot 3 \times 10^{-5} \\
1 \cdot 76 \times 10^{-5} \\
5 \cdot 8 \times 10^{-6}\end{array}$ & $\begin{array}{l}86 \\
93 \\
95\end{array}$ & $\begin{array}{l}17 \\
34 \\
87\end{array}$ & $\begin{array}{c}3.3 \times 10^{-5} \\
-\end{array}$ & $\frac{81}{-}$ & $\frac{4}{-}$ \\
\hline \multicolumn{6}{|c|}{ Citrate oxidation } \\
\hline $\begin{array}{l}2.65 \times 10^{-5} \\
1.76 \times 10^{-5} \\
5.8 \times 10^{-6}\end{array}$ & $\begin{array}{l}52 \\
55 \\
88\end{array}$ & $\begin{array}{l}16 \\
33 \\
68\end{array}$ & $\begin{array}{c}3.3 \times 10^{-5} \\
1.1 \times 10^{-5} \\
-\end{array}$ & $\begin{array}{l}77 \\
70 \\
\end{array}$ & $\begin{array}{r}0 \\
59 \\
-\end{array}$ \\
\hline
\end{tabular}


workers have shown that lewisite and arsenite react readily with dithiols such as BAL to form stable five-membered ring structures (Stocken \& Thompson, 1946b). Peters (1948), in his 'dithiol theory', suggested that arsenite and lewisite inhibited enzymes, the $\alpha$-keto acid oxidases, which contain dithiol groups. This view has been confirmed by the demonstration of lipoic acid in purified pyruvic oxidase (Schweet \& Cheslock, 1952) and $\alpha$-oxoglutaric oxidase (Sanadi, Littlefield \& Bock, 1952). The results given in this paper leave no reason to doubt that diethyltin dichloride could act in the same way as arsenite, phenylarsenious acid and lewisite. Some of our results with citrate as substrate (Fig. 1) suggest that for a comparable inhibition of oxygen uptake less $\alpha$-oxoglutarate accumulates with diethyltin dichloride than with phenylarsenious acid. Sufficient results are not yet available to substantiate this suggestion, but if true it would suggest that diethyltin dichloride has other actions at the concentrations which inhibit $\alpha$-oxoglutaric oxidase.

Diphenylchloroarsine possesses considerable affinity for monothiols and is a potent inhibitor, along with other SH reagents of $i$ socitric dehydrogenase (Lotspeich \& Peters, 1951). This inhibition is prevented by GSH. Diphenylchloroarsine inhibits oxidations of the tricarboxylic acid cycle and produces a slight accumulation of $\alpha$-keto acid with citrate and L-malate as substrate and no change with L-glutamate. The mechanism of inhibition of oxidation by diphenylchloroarsine is not known and our results produce no new ideas. However, the effect of diphenylchloroarsine is quite unlike that of triethyltin sulphate. Triethyltin sulphate possesses little or no affinity for the SH groups of BAL or GSH. With rat-brain brei or with rat-liver mitochondria a consistent lowering of $\alpha$-keto acid levels is found in the presence of triethyltin sulphate. The various steps of the respiratory chain are unaffected by approximately 100 times the concentrations effective against oxidation. Triethyltin sulphate has finally been shown to be a highly specific inhibitor of phosphorylation processes associated with oxidation. This finding poses many problems, of which three may be mentioned: (1) What is the mechanism of the inhibition of the phosphorylation process by triethyltin sulphate? (2) How does triethyltin sulphate interfere with oxidative processes? (3) Is the inhibition of phosphorylation found in vitro directly related to the clinical symtoms in vivo?

Practically nothing is known about the mechanism whereby energy derived from oxidation is converted into the phosphate bonds of ATP. The hypothesis that the triethyltin ion may replace some essential ion for the phosphorylation mechanism may be considered. Other substances, such as the SH reagents arsenite (Lehninger, 1949), iodoacetate and iodosobenzoate (Lehninger, 1949; Rothschild, Cori \& Barron, 1954) and $p$-chloromercuribenzoate (Lehninger, 1951), are known to prevent oxidative phosphorylation. Triethyltin sulphate, however, possesses little affinity for $\mathrm{SH}$ groups. Magnesium is generally accepted as an essential element for oxidative phosphorylation (Lehninger, 1949; Lardy, 1951). Barkulis \& Lehninger (1951) have shown that high concentrations of fluoride are inhibitory when AMP but not when ADP is used as a phosphate acceptor. They suggest that $A D P$ is the actual phosphate acceptor and that the inhibition by fluoride when AMP is used is due to inhibition of myokinase which requires magnesium (Kalckar, 1943). If this is so, an inhibition of myokinase when AMP is used as phosphate acceptor will result in a prevention of phosphorylation. This cannot be an explanation for the action of triethyltin sulphate, since the same inhibition of phosphorylation is produced with either ATP or AMP. ATP in the presence of hexokinase and glucose is converted into ADP which acts as the phosphate acceptor.

It has been pointed out that several SH reagents inhibit oxidative phosphorylation. These substances are far from specific and inhibit oxidative enzymes at similar or lower concentrations. We have been unable to show a direct action of triethyltin sulphate on any oxidative step and the respiratory chain is not affected. However, inhibition of oxygen uptake is a striking biochemical effect of triethyltin sulphate, but inhibition of phosphorylation always occurs first. It seems reasonable to assume that the inhibition of oxidation is a consequence of the inhibition of phosphorylation. 2:4-Dinitrophenol also inhibits phosphorylation at lower concentrations than those which inhibit oxidation, but the margin between these two effects is larger than for triethyltin sulphate. The results of the experiments using $\beta$-hydroxybutyrate as substrate suggest that one consequence of stopping or lowering the rate of phosphorylation is a loss of Co I. However, the interconversion of Co I and ATP should not be forgotten (Kornberg, 1950; Judah, 1951). The rate of oxygen uptake is not maintained in the presence of Co I, but this may be due to further loss of the added Co I; the experiments were carried out in the presence of nicotinamide, but it is not known whether Co I can be lost under these circumstances by a mode of degradation not preventable by nicotinamide. With more organized oxidation systems, such as the tricarboxylic acid cycle, other phosphorylated coenzymes are required. It could be proposed that with triethyltin sulphate, as with a medium without AMP, the oxidizing ability is lost by a loss of these coenzymes. However, in the presence of 
triethyltin sulphate, or in the absence of AMP, succinate oxidation is unimpaired. The prosthetic group of succinic dehydrogenase is not known with certainty (Neufeld, Scott \& Stotz, 1954), but it is certainly stable and not easily separated from the enzyme protein.

Stoner et al. (1955) have described in detail the clinical symptoms produced by injection of triethyltin sulphate into rats. With a dose of $10 \mathrm{mg} . /$ kg. body wt. the most characteristic symptom is generalized muscular weakness which persists until they die 3-4 days later. At higher doses this weakness is much more pronounced and the animals are comatose. A consistent pathological finding has been an oedema of the central nervous system (Magee, Stoner \& Barnes, unpublished). There appears to be no appreciable concentration of tin in any organ (Stoner et al. 1955); therefore, assuming that the triethyltin ion is distributed equally throughout the body water (75\% of body wt.), an $\mathrm{LD}_{50}$ dose of $6 \mathrm{mg} . / \mathrm{kg}$. body wt. would give a concentration of $3 \times 10^{-5} \mathrm{M}$. Upon this basis the inhibitory power of triethyltin sulphate on phosphorylation is sufficient to account for its toxicity. The symptoms are believed to have their origin in the central nervous system, and it should not be forgotten that most of our detailed experiments have been with liver mitochondria. However, our experiments with brain brei show that its inhibitory effect upon oxidation, which is presumably secondary to its effect on phosphorylation, occurs at similar concentrations to that on liver mitochondria. In view of the recent findings that many of the barbiturates inhibit oxidative phosphorylation (Brody \& Bain, 1951, 1954; Bain, 1952), it is tempting to suggest that the narcotic effects of barbiturates and the generalized muscular weakness produced by triethyltin sulphate have a common origin in the inhibition of oxidative phosphorylation. The statement by Bain (1952) that barbiturate anaesthesia is potentiated by 2:4-dinitrophenol and that the latter drug is itself a depressant is clearly of great interest in this connexion.

\section{SUMMARY}

1. Diethyltin dichloride and triethyltin sulphate are powerful metabolic poisons and have different modes of action.

2. Diethyltin dichloride, like phenylarsenious acid, inhibits $\alpha$-keto acid oxidases.

3. Triethyltin sulphate is a potent inhibitor of the phosphorylation processes associated with oxidation. No other action of triethyltin sulphate has been found.

We are grateful to Professor Sir Rudolph Peters, F.R.S., for helpful discussion, and to Mr B. W. Street for his skilled technical assistance. We are also grateful to Dr G. J. M. Van der Kerk for the supply of diethyltin dichloride, to Mr A. H. Ford-Moore for phenylarsine oxide, to Professor Sir Rudolph Peters for diphenylchloroarsine and to Mr W. R. Lewis for triethyltin hydroxide.

\section{REFERENCES}

Bain, J. A. (1952). Fed. Proc. 11, 653.

Barker, S. B. \& Summerson, W. H. (1941). J. biol. Chem. 138, 535.

Barkulis, S. S. \& Lehninger, A. L. (1951). J. biol. Chem. $190,339$.

Barron, E. S. G. \& Singer, T. P. (1945). J. biol. Chem. 157, 221.

Berger, L., Slein, M. W., Colowick, S. P. \& Cori, C. F. (1946). J. gen. Physiol. 29, 379.

Brenner-Holzach, O. \& Raaflaub, J. (1954). Helv. physiol. acta, 12, 242.

Brit. Med. J. (1954). 2, 693.

Brody, T. M. \& Bain, J. A. (1951). Proc. Soc. exp. Biol., N.Y., 77, 50.

Brody, T. M. \& Bain, J. A. (1954). J. Pharmacol. 110, 148.

Burton, K. \& Wilson, T. H. (1953). Biochem. J. 54, 86.

Christie, G. S. \& Iudah, J. D. (1953). Proc. Roy. Soc. B, $141,420$.

Clark, H. W., Neufeld, H. A., Widmer, C. \& Stotz, E. (1954). J. biol. Chem. 210, 851.

El Hawary, M. F. S. \& Thompson, R. H. S. (1953). Biochem. J. 53, 340.

Fiske, C. H. \& Subbarow, Y. (1925). J. biol. Chem. 66, 375.

Friedmann, T. E. \& Haugen, G. E. (1943). J. biol. Chem. $147,415$.

Grunert, R. R. \& Phillips, P. H. (1951). Arch. Biochem. 30, 217.

Gutcho, W. \& Stewart, E. D. (1948). Anal. Chem. 20, 1185.

Hellerman, L. (1937). Physiol. Rev. 17, 454.

Hogeboom, G. H. (1949). J. biol. Chem. 177, 847.

Horecker, B. L. \& Kornberg, A. (1948). J. biol. Chem. 175, 385.

Hullin, R. P. \& Noble, R. L. (1953). Biochem. J. 55, 289.

Judah, J. D. (1951). Biochem. J. 49, 271.

Kalckar, H. M. (1943). J. biol. Chem. 148, 127.

Keilin, D. \& Hartree, E. F. (1952). Biochem. Prep. $2,1$.

Keilin, D. \& Slater, E. C. (1953). Brit. med. Bull. 9, 89.

Kornberg, A. (1950). J. biol. Chem. 182, 779.

Kornberg, A. \& Pricer, W. E. (1953). Biochem. Prep. 3, 20.

Krebs, H. A. (1935). Biochem. J. 29, 1620.

Krimsky, I. \& Racker, E. (1949). J. biol. Chem. 179, 903.

Lardy, H. A. (1951). Phosphorus Metabolism, vol. 1, p. 477. Baltimore: Johns Hopkins Press.

Lehninger, A. L. (1949). J. biol. Chem. 178, 625.

Lehninger, A. L. (1951). Phosphorus Metabolism, vol. 1, p. 344. Baltimore: Johns Hopkins Press.

LePage, G. A. (1949). Biochem. Prep. 1, 5.

Lotspeich, W. D. \& Peters, R. A. (1951). Biochem. J. 49, 704.

Luijten, J. G. A. \& Van der Kerk, G. J. M. (1952). A Survey of the Chemistry and Applications of Organo-tin Compounds, p. 5. Tin Research Institute, Middlesex.

Macfarlane, M. G. \& Spencer, A. G. (1953). Biochem. J. 54, 569.

Neufeld, H. A., Scott, C. R. \& Stotz, E. (1954). J. biol. Chem. 210, 869. 
O'Brien, J. R. P. (1944). Brit. med. Bull. 2, 225.

Olson, J. A. \& Anfinsen, C. B. (1953). J. biol. Chem. 202, 841.

Peters, R. A. (1948). Brit. med. Bull. 5, 313.

Peters, R. A. (1952). Symposium on the Tricarboxylic Acid Cycle, 2nd Int. Congr. Biochem. Paris, p. 64.

Peters, R. A., Sinclair, H. M. \& Thompson, R. H. S. (1946). Biochem. J. 40, 516.

Price, C. A. \& Davies, R. E. (1954). Biochem. J. 58, xvii.

Racker, E. (1950). J. biol. Chem. 184, 313.

Robinson, H. W. \& Hodgen, C. G. (1940). J. biol. Chem. 135, 709.

Rothschild, H. A., Cori, O. \& Barron, E. S. G. (1954). J. biol. Chem. 208, 41.

Sanadi, D. R., Littlefield, J. W. \& Bock, R. M. (1952). J. biol. Chem. 197, 851.

Schneider, W. C. (1948). J. biol. Chem. 176, 259.

Schweet, R. S. \& Cheslock, K. (1952). J. biol. Chem. 199, 749 .
Slater, E. C. (1949). Biochem. J. 45, 14.

Smyth, C. P. (1941). J. org. Chem. 6, 421.

Stocken, L. A. \& Thompson, R. H. S. (1946a). Biochem. J. 40, 535 .

Stocken, L. A. \& Thompson, R. H. S. (1946b). Biochem. J. $40,529$.

Stoner, H. B., Barnes, J. M. \& Duff, J. M. (1955). Brit. J. Pharmacol. 10, 16.

Strittmatter, C. F. \& Ball, E. G. (1954). J. cell. comp. Physiol. 43, 57.

Umbreit, W. W., Burris, R. H. \& Stauffer, J. F. (1951). Manometric Techniques and Tissue Metabolism, p. 211. Minneapolis: Burgess Publishing Co.

Van der Kerk, G. J. M. \& Luijten, J. G. A. (1954). J. appl. Chem. 4, 314.

Walker, P. G. (1954). Biochem. J. 58, 699.

White, T. P. (1881). Arch. exp. Path. Pharmak. 13, 53.

Whitmore, F. C. \& Woodward, G. E. (1947). Org. Synth. (Collected), 1, 159.

\title{
[ $\left.{ }^{14} \mathrm{C}\right]$ Formate Labelling of Bases of Nucleic Acids in Respiring Slices of Rat Tissues
}

\author{
By W. A. MANNELL AND R. J. ROSSITER \\ Department of Biochemistry, University of Western Ontario, London, Canada
}

(Received 28 April 1955)

Alterations in the physiological status of small laboratory animals (e.g. by hormone administration, or by exposing them to a cold environment) frequently cause well-defined changes in the subsequent metabolism of tissue slices taken from certain organs. As part of a general study of such effects, it was of interest to investigate the labelling of nucleic acids in tissue slices. Because of the importance of formate as a precursor of purines (reviewed by Brown, Roll \& Weinfeld, 1952; Buchanan, 1952; Elwyn, 1953; Schulman, 1954), it was decided to investigate the possible incorporation of $\left[{ }^{14} \mathrm{C}\right]$ formate into the bases of ribonucleic acid (RNA) and deoxyribonucleic acid (DNA) in respiring slices.

Strangely enough, although there is a vast literature on the incorporation of small molecules into proteins, fatty acids and cholesterol in tissue slices, the nucleic acids have been studied less intensively. Much work has been done, however, on the formation of hypoxanthine in pigeon-liver preparations (summarized by Schulman, 1954).

Labelled inorganic phosphate is incorporated into the RNA of respiring slices of brain (DeLuca, Rossiter \& Strickland, 1953) and of pancreas (Hokin \& Hokin, 1954). In experiments of this type, most RNA preparations are contaminated with small amounts of highly radioactive phos- phorus-containing compounds. For this reason, an unequivocal incorporation of the label into RNA had to await the development of adequate analytical methods (Davidson, Frazer \& Hutchinson, 1951; Davidson \& Smellie, 1952; DeLuca et al. 1953). With ${ }^{14} \mathrm{C}$-labelled precursors, the earlier experiments were more convincing. Abrams, Goldinger \& Barron (1950) showed that both RNA and DNA of bone-marrow slices were labelled from [carboxy- ${ }^{14} \mathrm{C}$ ] acetate. However, since Bernstein (1952) reported that [carboxy $\left.-{ }^{14} \mathrm{C}\right]$ acetate was incorporated into the ribose of RNA, it is not certain whether the bases or the sugars of the nucleic acids were labelled in these experiments. Reichard \& Bergstrom (1951) showed that $\left[{ }^{15} \mathrm{~N}\right]$ glycine was incorporated into the purines of RNA and DNA of slices of regenerating liver, and, using a similar preparation, Lagerkvist, Reichard \& Ehrensvärd (1951) and Reichard \& Lagerkvist (1953) showed that labelled aspartic acid was incorporated into orotic acid and RNA pyrimidines. LePage (1953) reported that the purines of RNA and DNA were labelled from $\left[\alpha^{-14} \mathrm{C}\right]$ glycine in liver and tumour preparations. Using bone-marrow slices, Abrams \& Goldinger (1951) found that [carboxy $\left.-{ }^{14} \mathrm{C}\right]$ glycine and $\left[{ }^{14} \mathrm{C}\right]$ formate (Abrams \& Goldinger, 1952) were incorporated into the purines of both RNA and DNA. Totter (1954) showed that, in addition to the 